\title{
Role if ATM IVS10-6T $\rightarrow$ G Polymorphism in Breast Cancer; A Case-control Study in High-risk Kashmiri Population
}

\author{
Nidda Syeed ${ }^{1,2}$, Firdous Hussain ${ }^{1,2}$ and Mushtaq A Siddiqi ${ }^{1^{*}}$ \\ ${ }^{1}$ Departments of Immunology and Molecular Medicine, Sher-I-Kashmir Institute of Medical Sciences, Soura, Srinagar, Kashmir, India \\ ${ }^{2}$ Department of Applied Medical Sciences, King Khalid University, Saudi Arabia
}

*Corresponding author: Dr. Mushtaq A Siddiqi, Professor and Chief, Department of Immunology and Molecular Medicine, Sher-i-Kashmir Institute of Medical Sciences, Soura, Srinagar, Kashmir-190011, India, Tel: +91-194-2401013; Fax: +91-194-2403470; E-mail: siddiqmush@gmail.com

Received date: Jan 20, 2014, Accepted date: Feb 19, 2014, Published date: Feb 25, 2014

Copyright: (C) 2014 Siddiqi MAT, et al. This is an open-access article distributed under the terms of the Creative Commons Attribution License, which permits unrestricted use, distribution, and reproduction in any medium, provided the original author and source are credited.

\begin{abstract}
The provenance of $A T M$ candidacy as a susceptible breast cancer gene stems from two sources. The main task of $A T M$ being that the ATM protein is a fundamental participant in mediating cellular responses to DNA damage, including cellular signaling, DNA double-strand break repair and leading to cell-cycle arrest and apoptosis. From the genetic standpoint, ATM is a gene mutated in ataxia-telangiectasia (AT), an autosomal recessive disorder phenotypically characterised by chromosomal instability and an increased risk for lymphoproliferative tumors in homozygotes. Numbers of studies have suggested that heterozygous carriers of ATM mutations are at increased risk of breast cancer and $A T M I V S 10-6 T \rightarrow G$ SNP has been reported to significantly increase the breast cancer risk. In order to shed further light on the putative contribution of ATM to breast cancer risk, we performed haplotyping of the ATM locus in high-risk Kashmiri population. The ATM IVS10-6T $\rightarrow$ G polymorphism was studied in 130 breast cancer patients and 220 female healthy controls using a PCR-RFLP (polymerase chain reaction-restriction fragment length polymorphism) and conformation by DNA Sequencing. The PCR-RFLP analysis revealed that $68.4 \%$ (89 of 130) breast cancer patients were homozygous for $T / T$ variant, $21.5 \%$ (28 of 130) patients were heterozygous for $T / G$ variant and $10 \%$ (13 of 130) patients were homozygous for GG variant. The present study concludes that the ATM IVS10-6T $\rightarrow G$ polymorphism is associated with sufficiently high risk of breast cancer and among the breast cancer cases and controls the heterozygous $T / G$ variant determines the higher risk for initiating and developing breast cancer.
\end{abstract}

\begin{abstract}
Keywords: Kashmir; Breast cancer; ATM; PolymorphismAbbreviations: ATM: Ataxia Telangiectasia Mutated; SNP: Single Nucleotide Polymorphism; PCR-RFLP: Polymerase Chain Reaction-Restriction Fragment Length Polymorphism; BRCA1: Breast Cancer Gene 1; BRCA2: Breast Cancer Gene 2
\end{abstract}

\section{Introduction}

Breast cancer is the second most frequent cancer in the world and is by far the most common malignant disease in women, with an incidence of 1.05 million new cases per year, accounting for $22 \%$ of all new cancer cases [1]. It continues to be a major burden and cause of death among women worldwide. Breast cancer has been associated with a variety of risk factors [2] both genetic and epigenetic [3]. The Development of human breast cancer arises from various genetic alterations that drive the transformation of normal mammary epithelial cells into highly malignant derivatives [4]. To encounter these alterations, breast cells have developed diverse pathways that are involved to repair different types of DNA damage and maintain genomic integrity. Several studies have reported that paucity in the DNA repair capacity may lead to deletions, amplifications, and/or mutations of critical genes that contribute to breast carcinogenesis $[5,6]$.

Kashmir valley is located at an altitude of 1800-2400 m from the sea level in the northern division of India. The distinctive ethnic population of the valley, in terms of its unique geographical locale, intra-community marriages, preserved genetic pool and food habits. In the valley, breast cancer incidence has shown an increasing tendency over the last couple of decades, concerning the female population of the valley. In fact, breast cancer has reached second most common cancer among females. A total of 6943 cases newline registered between 1st January 2002 to 31st December 2006 comprised of 4345 males and 2598 females [7].

ATM is located on chromosome 11q22.3. The ATM gene encodes a protein of 3056 amino acids with a molecular weight of $350 \mathrm{kDa}$ [8]. ATM belongs to the super family of Phosphatidylinositol 3-kinaserelated kinases [PIKKs]. As has been stated earlier, that ATM gene mutations result in defective G1-S checkpoint control of the cell cycle that is mediated through the p53, p21/cip1, cyclin dependent kinases, and retinoblastoma protein and signal transduction pathways [9-11]. In addition, it has recently been reported [12] that two other genes that are in the proximity of the ATM locus might be involved in breast cancer development and progression. The ATM kinase plays a vital role in preserving the genomic integrity. It is a crucial activator of the cellular responses to DNA double-strand breaks [13]. Mutations in the ATM gene cause ataxia-telangiectasia [A-T] [14], which is a rare recessive disorder involving, cell cycle checkpoint defects, progressive neurodegeneration, and increased risk for cancer [15]. As has been reported earlier that ionizing radiation and other agents that cause double-strand breaks in DNA, by defects in both the G1/S and G2/M checkpoint responses, by defective inhibition of DNA replication, and by defective production of p53 in response to ionizing radiation is associated with an increased risk of breast cancer, hence the function of the ATM protein in repairing the double strand breaks of DNA, makes it a significant candidate in breast cancer predisposition [16]. 
ATM might be a breast cancer susceptibility gene, first came from studies describing that increased breast cancer risk among obligate heterozygous mutation carriers in A-T families [17,18], thus, an increased risk for breast malignancy, among individuals heterozygous for germline ATM mutations has been reported in several studies $[19,20]$. ATM mutation IVS10-6T $\rightarrow \mathrm{G}$, possess increased breast cancer risk by about nine fold. Further attributing to the role of ATM in breast cancer one more study has described the classical A-T with homozygous IVS10-6T $\rightarrow \mathrm{G}$ mutations in breast cancer [21], which depicts that this mutation is clearly pathogenic. This mutation leads to incorrect splicing of exon 11 and exon skipping, resulting in a frame shift starting at codon 355 and subsequent truncation of the protein at amino acid 419. The overall effect leads to the increased risk for development of breast cancer.

The substantiation on the subject concerning the role of ATM as a breast cancer susceptibility gene has been contradictory. By and large, the incidence of ATM mutations found in breast cancer patients in the general population has been low, and many of the ATM variants found are too rare to be evaluated. These results have encouraged the alternative methods to determine the role of ATM in breast cancer susceptibility. As has been proposed that missense variants predispose to breast cancer [22], it has been suggested that only a subset of ATM mutations, that are distinct due to specific biological characteristics, confer a risk of breast cancer, that is high, parallel to that of mutations caused by BRCA1 and BRCA2 [23].

To crack the dilemma regarding the role of ATM mutations in breast cancer susceptibility, we adopted a case-control strategy that will shed further light on the putative contribution of ATM in breast cancer risk. In the present study, we evaluated the IVS10-6T $\rightarrow \mathrm{G}$ variant, which is believed to be greatly involved in breast cancer predisposition and development [21].

\section{Materials and Methods}

\section{Study population and tumor tissue procurement}

This study included 130 randomly selected breast cancer patients. All patients included in the study were both male and female. All breast cancer patients were recruited from Department of Surgery, Sher-I-Kashmir Institute of Medical Sciences, from March 2008 to Jan 2010. Tumor types and stages were determined by two experienced pathologists. Blood samples of 220 age and sex matched cases with no signs of any malignancy were collected for controls.

Data on all breast cancer patients were obtained from personal interviews with patients and/or guardians, medical records and pathology reports. The data collected included sex, age, dwelling, tumor location, lymph node status, Menopausal status. All patients and/or guardians were informed about the study and their will to participate in this study was taken on predesigned questionnaire. The collection and use of tumor and blood samples for this study were previously approved by the appropriate Institutional Ethical Committee.

\section{Controls}

Patients attending the Department of general medicine at Sher-IKashmir Institute of Medical Sciences [SKIMS] for general check-up were screened. A total of 260 patients visited the SKIMS, out of 260 patients only 220 agreed to take part in the present study, henceforth written informed consent was obtained from all patients for their participation.

\section{DNA isolation}

Genomic DNA was extracted from tissue samples, peripheral blood samples and control blood samples using DNA Extraction Kit [Qiagen, USA]. The quality of the resulting genomic DNA was stringently assessed by low percentage agarose gel electrophoresis followed by UV spectrophotometer.

\section{PCR-RFLP analysis}

ATM IVS10-6T $\rightarrow$ G: In our study, polymerase chain reaction [PCR]restriction fragment length polymorphism [RFLP] assays were used for screening the ATM IVS10-6T $\rightarrow$ G and T7271G variant using the primers from earlier studied report [23]. Each PCR reaction was performed in a 50 ul final volume containing 20 to $100 \mathrm{ng}$ of genomic DNA, $10 \mathrm{mmol} / \mathrm{L}$ Tris-HCl, $10 \mathrm{pmol} / \mathrm{L}$ of each primer, $200 \mathrm{umol} / \mathrm{L}$ of each dNTP, and $1 \mathrm{U}$ of Taq DNA polymerase [Genei, India]. PCR was performed in a thermal cycler [Biorad icycler]. Both positive and negative controls were used in each PCR reaction. PCR products were run on $1.8 \%$ agarose gel and analyzed under UV illuminator.

The PCR products [20 ul] were digested for $16 \mathrm{~h}$ at $37^{\circ} \mathrm{C}$ with 1 unit of RsaI for ATM IVS10-6T $\rightarrow$ G Deletion [Fermentas Inc, Vilnius, Lithuania], where the $\mathrm{G}$ allele produced two bands [58 and $135 \mathrm{bp}$ ]; $\mathrm{T}$ allele, which lacks a RsaI restriction site, was identified by a single 193bp product.

Direct Sequencing: PCR amplicons of the tumor samples and from randomly chosen normal samples were first purified by DNA recovery kit (Zymo Research, USA) and then used for direct DNA sequencing. DNA sequencing was carried out at MACROGEN INC, Korea. To minimize the sequencing artifacts by PCR, products from at least two different PCRs were sequenced using forward and reverse primers.

Statistical analysis: Observed frequencies of genotypes in breast cancer patients were compared to controls using chi-square or Fisher exact tests when expected frequencies were small. The chi-square test was used to verify whether genotype distributions were in HardyWeinberg equilibrium. Statistical significance was set at $\mathrm{P}<0.05$. Statistical analyses were performed with PASW version 18 Software.

\begin{tabular}{|c|c|c|c|c|c|}
\hline \multirow[t]{2}{*}{ Variables } & \multicolumn{5}{|c|}{ Cases $(n=130)$} \\
\hline & $\begin{array}{l}\text { Total } \\
\mathrm{N}=130\end{array}$ & $\begin{array}{l}\text { TT } \\
89(68.4 \%)\end{array}$ & $\begin{array}{l}\text { TG } \\
28(21.5 \%)\end{array}$ & $\begin{array}{l}\text { GG } \\
13(10.0 \%)\end{array}$ & P Value; $x^{2}$ \\
\hline $\begin{array}{l}\text { Dwelling } \\
\text { Rural: } \\
\text { Urban: }\end{array}$ & $\begin{array}{l}45(34.6 \%) \\
85(65.4 \%)\end{array}$ & $\begin{array}{l}25(28.08 \%) \\
64(71.91 \%)\end{array}$ & $\begin{array}{l}13(46.42 \%) \\
15(53.57 \%)\end{array}$ & $\begin{array}{l}7(7.69 \%) \\
6(46.15 \%)\end{array}$ & $0.06 ; 5.53$ \\
\hline
\end{tabular}


Page 3 of 5

\begin{tabular}{|c|c|c|c|c|c|}
\hline $\begin{array}{l}\text { Menopausal Status } \\
\text { Pre: } \\
\text { Post: }\end{array}$ & $\begin{array}{l}36(27.7 \%) \\
94(72.3 \%)\end{array}$ & $\begin{array}{l}18(20.22 \%) \\
71(79.77 \%)\end{array}$ & $\begin{array}{l}10(35.71 \%) \\
18(64.28 \%)\end{array}$ & $\begin{array}{l}8(61.53 \%) \\
5(38.46 \%)\end{array}$ & $0.00 ; 10.82$ \\
\hline $\begin{array}{l}\text { Tumor Stage } \\
\mathrm{II}(\mathrm{a}+\mathrm{b}) \\
\mathrm{II}(\mathrm{a}+\mathrm{b})+\mathrm{IV}\end{array}$ & $\begin{array}{l}72(55.4 \%) \\
58(44.6 \%)\end{array}$ & $\begin{array}{l}45(50.56 \%) \\
44(49.43 \%)\end{array}$ & $\begin{array}{l}22(78.57 \%) \\
6(21.42 \%)\end{array}$ & $\begin{array}{l}5(38.46 \%) \\
8(61.53 \%)\end{array}$ & $0.01 ; 8.44^{\prime}$ \\
\hline $\begin{array}{l}\text { Histopathological Tumor } \\
\text { Grade } \\
\text { PD } \\
\text { MD+WD }\end{array}$ & $\begin{array}{l}25(19.23 \%) \\
58+47(80.76 \%)\end{array}$ & $\begin{array}{l}14(15.73 \%) \\
75(84.26 \%)\end{array}$ & $\begin{array}{l}6(21.42 \%) \\
22(78.57 \%)\end{array}$ & $\begin{array}{l}5(38.46 \%) \\
8(61.53)\end{array}$ & $0.14 ; 3.38$ \\
\hline
\end{tabular}

Table 1: Association between ATM gene IVS10-6T $\rightarrow$ G and clinico-pathologic characteristics

\section{Results}

\section{Clinicopathological characteristics of patients}

A total of 130 breast cancer patients were included in the study and 220 normal controls. Out of 130 breast cancer patients, 113 patients were below 50 years of age and 17 were of 50 years of age or more. 72 patients had grade I and II tumor, and 58 had grade III and IV tumor status.105 breast cancer patients had widely or moderately differentiated histopathological grade and 25 had poorly differentiated histopathological grade. 36 patients were in the pre-menopausal stage while as 94 patients were in the post-menopausal stage. Table 1 shows clinico-pathological characteristics related to the TT, TG and GG variants.

\section{ATM IVS10-6T $\rightarrow$ G genotype of the Breast Cancer patients}

We determined the ATM IVS10-6T $\rightarrow G$ genotype in 130 breast cancer patients; we found $68.4 \%$ [ 89 of 130 ] patients were homozygous for T/T variant, $21.5 \%$ [ 28 of 130 ] patients were heterozygous for $T / G$ variant and $10 \%$ [ 13 of 130] patients were homozygous for $G G$ variant. ATM IVS10-6T $\rightarrow G$ was significantly associated with menopausal status and tumor stage. The power of calculation was 0.99 in one side test (Table 1).

In this study the observed genotype frequencies in cases and controls were in Hardy-Weinberg equilibrium. The genotype frequencies of $A T M$ IVS10-6T $\rightarrow \mathrm{G}$ in cases and controls were observed and it was found that TG genotype is significantly associated with the breast cancer cases ( $\mathrm{p}$ value $=0.001$ ) Table 2 .

\begin{tabular}{|l|l|l|l|}
\hline ATM Genotype & Cases $(\mathrm{n}=130)$ & Controls $(\mathrm{n}=220)$ & $\begin{array}{l}\text { OR }(95 \% \mathrm{Cl}) ; \quad p \\
\text { value }\end{array}$ \\
\hline TT & $89(47.6 \%)$ & $120(54.54 \%)$ & $\begin{array}{l}0.55 ; \\
0.01\end{array}$ \\
\hline TG & $28(33.07 \%)$ & $80(36.36 \%)$ & $\begin{array}{l}2.08 ; \\
0.004\end{array}$ \\
\hline GG & $13(19.23 \%)$ & $20(9.09 \%)$ & $0.96-3.43 ;$ \\
& & & 0.85 \\
\hline
\end{tabular}

Table 2: Genotype frequencies of ATM gene polymorphism in cases and controls and their associations with the risk of breast cancer patients of Kashmir valley

\section{Discussion}

Breast cancer continues to be the most common malignancies in women. The genome of breast cancer cells in general are considered unstable. Based on the biological plausibility, apart from the highly penetrant genes like $B R C A 1$ and $B R C A 2$, intermediate and lowpenetrance genes are usually chosen among the genes in which even a subtle change could have an effect on the biochemical pathways that influence carcinogenesis, this has been the main driving force of our study, as ATM being considered as a low penetrant gene.

The ataxia telangiectasia mutated (ATM) gene is a tumor suppressor gene, involved in repairing the damaged DNA. ATM plays a major role in cell cycle arrest, apoptosis, and repair of DNA doublestrand breaks. AT cells are receptive towards agents that cause doublestrand breaks, due to their impaired checkpoint control and lack of ability to repair DNA damage. Inheriting abnormal copies of this gene causes the disease ataxia-telangiectasia. One copy of this mutated gene if inherited results in high rate of breast cancer. Furthermore, ATM also plays critical role in the regulation of $B R C A 1$, which adds to the evidence that ATM has a significant role in breast cancer $[24,25]$. As has been reported earlier that the A-T carrier frequency of $1 \%$ increases the breast cancer risk by threefold, it was suggested that A-T heterozygosity may account for about $5 \%$ of all breast cancers [26], which is much greater than the $1-2 \%$ attributable to mutations in BRCA1 and BRCA2.

The study is carried in the Kashmir valley which is present at a high altitude, with mostly consanguineous marriages resulting in preservation of the genetic pool. As has been reported earlier breast cancer is a heterogeneous disease, and many risk factors are responsible in the development of breast cancer [27,28]. It has been put forward that the frequency of ATM polymorphism vary according to ethnic group; hence we performed the study to analyse the role of ATM polymorphism in breast cancer patients in our ethnic population. The main aim of our study was to predict the predisposition towards the development of breast cancer due to single nucleotide ATM polymorphism.

In our current study, we studied the ATM IVS10-6T $\rightarrow \mathrm{G}$ polymorphism in breast cancer patients and control subjects. IVS10-6T $\rightarrow$ G is present at the exon 11 splice-site, as has been reported earlier [29] that this mutation occurs frequently among the breast cancer patients, suggesting that this particular ATM mutation might be associated with an increased risk of breast cancer in ATM heterozygote's. IVS10-6T $\rightarrow$ G leads to incorrect splicing of exon 11 and exon skipping, resulting in a frame shift starting at codon 355 and 
subsequent truncation of the protein at amino acid 419. The overall effect leads to the increased risk for development of breast cancer. From the earlier reports, it is quite clear that that the ATM allele which is involved in the stabilization and phosphorylation of p53 gets mutated, which is supposed to decreases the efficiency of the G1/S checkpoint and also leads to defective DNA damage-induced phosphorylation of BRCA1. The mutant ATM allele might exert a dominant negative effect on the wild-type allele by inducing direct competition with wild-type protein for binding to key substrates and regulators, such as the $\mathrm{p} 53$ and BRCA1 proteins [27,28].

The objective of the present study was to assess the role of common variation in ATM and breast cancer risk. $68.4 \%$ breast cancer patients were homozygous for $\mathrm{T} / \mathrm{T}$ variant, $21.5 \%$ patients were heterozygous for $\mathrm{T} / \mathrm{G}$ variant and $10 \%$ patients were homozygous for $\mathrm{GG}$ variant

We found the ATM IVS10-6G $\rightarrow$ T mutation is significantly associated with the menopausal status suggesting that mammary tumorigenesis is commonly initiated during pre-menopausal stages as has been reported earlier [29].

ATM IVS10-6G $\rightarrow$ T mutation was also found to be statistically significant with tumor grade [III+IV], which suggests that ATMmediated DNA damage response [DDR] signalling most likely plays a critical role in progression of tumors.

We also found that the genotype frequencies of ATM IVS10-6G $\rightarrow \mathrm{T}$ in cases and controls, where TG genotype is significantly associated with the breast cancer cases ( $\mathrm{p}$ value $=0.001$ ), suggesting that the breast cancer patients carrying a TG allele are at much higher risk for breast cancer.

Although, the role of ATM in breast cancer susceptibility has been controversial for about 20 years. However, our results support the hypothesis that ATM heterozygotes do have an increased risk of development of breast cancer. The current study is the first to report ATM SNP in a population of high-risk Kashmiri population. It is worth mentioning that specific genotypes are associated with breast cancer risk even without performing the segmential process.

\section{Conflict of Interest}

The contributing Authors have no financial or any non-financial competing interests.

\section{Authors' Contributions}

Nidda Syeed and Firdous Hussain formulated, designed and performed the lab work for the study. Mushtaq A Siddiqi coordinated the study, revised the manuscript and entire work was done under his supervision. All authors have read and approved the final manuscript.

\section{Acknowledgements}

The authors gratefully acknowledge the Sher-I-Kashmir Institute of Medical Sciences, Kashmir for providing funds for this research work. The present research was not funded by any funding agency. The collection of cancer samples used in this study was supported by the Department of general surgery, Sher-I-Kashmir institute of medical sciences.

The authors would like to thank all the breast cancer patients who participated in the study who are responsible for the creation and maintenance of the entire group within which this study was conducted but were not involved in the current paper.

\section{References}

1. Parkin DM. Global cancersta tistics in the year 2000 (2001) Lancet Oncol; 2: 532-542.

2. Kaaks R, Rinaldi S, Key TJ, Berrino F, Peeters PH, et al. (2005) Postmenopausal serum androgens, oestrogens and breast cancer risk: the European prospective investigation into cancer and nutrition. Endocr Relat Cancer 12: 1071-1082.

3. Xie GS, Hou AR, Li LY, Gao YN, Cheng SJ (2006) Aberrant p16 promoter hypermethylation in bronchial mucosae as a biomarker for the early detection of lung cancer. Chin Med J (Engl) 119: 1469-1472.

4. Hanahan D, Weinberg RA: (2000) The hallmarks of cancer Cell; 100; 57-70.

5. Helzlsouer KJ, Harris EL, Parshad R, Perry HR, Price FM, et al. (1996) DNA repair proficiency: potential susceptiblity factor for breast cancer. J Natl Cancer Inst 88: 754-755.

6. Hu JJ, Smith TR, Miller MS, Lohman K, Case LD (2002) Genetic regulation of ionizing radiation sensitivity and breast cancer risk. Environ Mol Mutagen 39: 208-215.

7. Only Kashmir. Breast cancer in Kashmir on rise

8. Savitsky K, Sfez S, Tagle DA, Ziv Y, Sartiel A, et al. (1995) The complete sequence of the coding region of the ATM gene reveals similarity to cell cycle regulators in different species. Hum Mol Genet 4: 2025-2032.

9. Canman CE, Wolff AC, Chen CY, Fornace AJ Jr, Kastan MB (1994) The p53-dependent G1 cell cycle checkpoint pathway and ataxiatelangiectasia. Cancer Res 54: 5054-5058.

10. Kastan MB, Zhan Q, el-Deiry WS, Carrier F, Jacks T, et al. (1992) A mammalian cell cycle checkpoint pathway utilizing p53 and GADD45 is defective in ataxia-telangiectasia. Cell 71: 587-597.

11. Khanna KK, Jackson SP (2001) DNA double-strand breaks: signaling, repair and the cancer connection. Nat Genet 27: 247-254.

12. Laake K, Odegård A, Andersen TI, Bukholm IK, Kåresen R, et al. (1997) Loss of heterozygosity at 11q23.1 in breast carcinomas: indication for involvement of a gene distal and close to ATM. Genes Chromosomes Cancer 18: 175-180.

13. Shiloh Y (2003) ATM and related protein kinases: safeguarding genome integrity. Nat Rev Cancer 3: 155-168.

14. Savitsky K, Bar-Shira A, Gilad S, Rotman G, Ziv Y, et al. (1995) A single ataxia telangiectasia gene with a product similar to PI-3 kinase. Science 268: 1749-1753.

15. Lavin MF, Shiloh Y (1997) The genetic defect in ataxia-telangiectasia. Annu Rev Immunol 15: 177-202.

16. Khanna KK, Chenevix-Trench G (2004) ATM and genome maintenance: defining its role in breast cancer susceptibility. J Mammary Gland Biol Neoplasia 9: 247-262.

17. Swift M, Reitnauer PJ, Morrell D, Chase CL (1987) Breast and other cancers in families with ataxia-telangiectasia. $N$ Engl J Med 316: 1289-1294.

18. Swift M, Morrell D, Massey RB, Chase CL (1991) Incidence of cancer in 161 families affected by ataxia-telangiectasia. $N$ Engl J Med 325: 1831-1836.

19. Olsen JH, Hahnemann JM, Børresen-Dale AL, Brøndum-Nielsen K, Hammarström L, et al. (2001) Cancer in patients with ataxiatelangiectasia and in their relatives in the nordic countries. J Natl Cancer Inst 93: 121-127.

20. Thompson D, Duedal S, Kirner J, McGuffog L, Last J, et al. (2005) Cancer risks and mortality in heterozygous ATM mutation carriers. J Natl Cancer Inst 97: 813-822.

21. Dörk T, Bendix R, Bremer M, Rades D, Klöpper K, et al. (2001) Spectrum of ATM gene mutations in a hospital-based series of unselected breast cancer patients. Cancer Res 61: 7608-7615. 
Citation: Syeed N, Hussain F, Siddiqi MA (2014) Role if ATM IVS10-6T $\rightarrow$ G Polymorphism in Breast Cancer; A Case-control Study in High-risk Kashmiri Population. J Carcinog \& Mutagen 5: 163. doi:10.4172/2157-2518.1000163

Page 5 of 5

22. Gatti RA, Tward A, Concannon P (1999) Cancer risk in ATM heterozygotes: a model of phenotypic and mechanistic differences between missense and truncating mutations. Mol Genet Metab 68: 419-423.

23. Chenevix-Trench G, Spurdle AB, Gatei M, Kelly H, Marsh A, et al. (2002) Dominant negative ATM mutations in breast cancer families. J Natl Cancer Inst 94: 205-215.

24. Li S, Ting NS, Zheng L, Chen PL, Ziv Y, et al. (2000) Functional link of BRCA1 and ataxia telangiectasia gene product in DNA damage response. Nature 406: 210-215.

25. Thorstenson YR, Shen P, Tusher VG, Wayne TL, Davis RW, et al. (2001) Global analysis of ATM polymorphism reveals significant functional constraint. Am J Hum Genet 69: 396-412.
26. Girard PM, Riballo E, Begg AC, Waugh A, Jeggo PA (2002) Nbs1 promotes ATM dependent phosphorylation events including those required for G1/S arrest. Oncogene 21: 4191-4199.

27. Tauchi H, Kobayashi J, Morishima K, Matsuura S, Nakamura A, et al. (2001) The forkhead-associated domain of NBS1 is essential for nuclear foci formation after irradiation but not essential for hRAD50[middle dot]hMRE11[middle dot]NBS1 complex DNA repair activity. J Biol Chem 276: 12-15.

28. Easton DF (1994) Cancer risks in A-T heterozygotes. Int J Radiat Biol 66 S177-182.

29. Broeks A, Urbanus JH, Floore AN, Dahler EC, Klijn JG, et al. (2000) ATM-heterozygous germline mutations contribute to breast cancersusceptibility. Am J Hum Genet 66: 494-500. 